\title{
Production, characterization, and immobilization of protease from the yeast Rhodotorula oryzicola
}

\author{
Juliana Mota de Oliveira ${ }^{1}$ \\ Pedro Fernandes ${ }^{2,3}$ \\ Raquel Guimarães Benevides ${ }^{1}$ \\ Sandra Aparecida de Assis (D) ${ }^{*}$
}

\author{
${ }^{1}$ Enzymology and Fermentation Technology Laboratory, Health \\ Department, State University of Feira de Santana, Feira de Santana, Bahia, \\ Brazil \\ ${ }^{2}$ DREAMS and Faculty of Engineering, Lusófona University, Lisbon, \\ Portugal \\ ${ }^{3}$ Department of Bioengineering, IBB - Institute for Bioengineering and \\ Biosciences, Instituto Superior Técnico, University of Lisbon, Lisbon, \\ Portugal
}

\section{Abstract}

The protease was produced extracellularly in submerged fermentation by the yeast Rhodotorula oryzicola using different sources of nitrogen and maximum activity $(6.54 \times$ $10^{-3} \mathrm{U} / \mathrm{mg}$ ) was obtained in medium containing $2 \%$ casein $(w / v)$. Purification of the protease by gel filtration chromatography resulted in a 3.07-fold increase of specific protease activity. The optimal $\mathrm{pH}$ and temperature for enzyme activity were 6.51 and $63.04{ }^{\circ} \mathrm{C}$, respectively. Incubation in the presence of some salts enhanced enzyme activity, which peaked under $0.01 \mathrm{M} \mathrm{BaCl}_{2}$. The enzyme retained about $90 \%$ of enzymatic activity at temperatures $50-60^{\circ} \mathrm{C}$. The commercially available enzyme carriers evaluated, silica gel, Celite 545, and chitosan effectively immobilized the protease. The enzyme immobilized in Celite 545 retained $73.53 \%$ of the initial activity after 15 reuse cycles. These results are quite promising for large-scale production and immobilization of protease from $R$. oryzicola, as the high operational stability of the immobilized enzyme lowers production costs in biotechnological applications that require high enzymatic activity and stability under high temperatures. (c) 2020 International Union of Biochemistry and Molecular Biology, Inc. Volume 0, Number 0, Pages 1-11, 2020

Keywords: adsorption, Celite 545, immobilization, protease, reuse, silica gel

\section{Introduction}

Enzymes are used as catalysts to induce chemical reactions and boost production processes. They are used in several chemical and industrial processes, such as tanning, brewing, baking, animal feed, and biofuel production [1]. The enzyme market was responsible for generating about US\$ 4.61 billion

\footnotetext{
*Address for correspondence: Sandra Aparecida de Assis, Enzymology and Fermentation Technology Laboratory, Health Department, State University of Feira de Santana, Av. Transnordestina, km 0, BR 116, 44036-900 Feira de Santana, Bahia, Brazil. Tel.: +557575) 3161-8341;

e-mail: sandrinhaassis@yahoo.com.br

DOI: $10.1002 /$ bab.2023

Published online in Wiley Online Library

(wileyonlinelibrary.com)
}

2022. This growing demand is related to the expansion of foodprocessing facilities and the increasing number of tanneries and textile-manufacturing facilities [2].

in 2016, and this value is expected to reach US\$ 6.30 billion in
Brazil is an enzyme-importing country, and enzymes are still scarcely used in industrial processes when compared to other countries. Thus, there is an urge to close this gap and establish Brazil as a major player in enzyme technology [3].

Enzymes can have a key role in many industries that strive to implement processes that meet the demands of a rapidly growing population, while dealing with the depletion of natural resources [4]. The use of enzymes allows industries to address both regulations and customer demands for clean technologies and clean, sustainable production methods, altogether resulting in low environmental impacts. Such strategy provides a viable solution for the next generation of production and manufacturing due to reduced costs, energy expenditures, use of water and chemicals, and production time [5-7]. The growing worldwide awareness towards the need 


\section{Highlights}

- Rhodotorula oryzicola was used to obtain protease.

- Protease was purified by gel filtration chromatography.

- Silica gel, Celite, and chitosan effectively immobilized the protease.

- Protease immobilized in Celite retained $73.53 \%$ of the initial activity after 15 reuse cycles.

for less pollution and cleaning the environment has favored the gradual replacement of chemical processes by enzymatic processes [3,8].

Enzymes of microbial origin have significant potential in waste management and consequently in the development of the environment, unlike enzymes of plant origin that need large planting areas and have greater requirements as to climatic factors and seasons for their development $[4,8]$.

Microorganisms are the main source of these enzymes, as they are able to use a vast array of low-cost, widely available substrates and are easily grown on a large scale, allowing for high-yield enzyme production through faster, easier, and lower cost processes, and releasing an impressive amount of biocatalysts for different culture media [9-12].

Among the various types of enzymes, proteases have stood out in the industrial environment, leading the market in 2016 [1]. There are already studies indicating that the addition of protease in fermentations, such as corn fermented to ethanol, can generate potential savings due to lower costs involved [13].

Proteases are responsible for catalyzing the hydrolysis of protein molecules into large fragments, and peptidases hydrolyze these polypeptide fragments into amino acids. They can be classified as acidic, neutral, or alkaline proteases according to the $\mathrm{pH}$ at which they become active $[14,15]$. Due to the industrial demand for proteolytic enzymes with high specificity and stability, the search for new sources of these enzymes continues to be encouraged [16].

The use of yeasts as a source of biocatalysts has some advantages, such as production of high concentrations of enzymes, shorter fermentation cycles, use of low-cost fermentation media, and high diversity of enzymes that catalyze the same reaction, which allows flexibility in conditions of use and low pathogenicity [17].

The ability of the genus Rhodotorula to produce different enzymes of industrial interest is known within the scientific community. These enzymes include phenylalanine ammonium lyase [18], fructosyltransferase [19], $\beta$-fructofuranosidase [20], superoxide dismutase, catalase [21], and laccase [22], with main applicability to the food industry. Moreover, production of proteolytic enzymes has been reported for these species $R$. mucilaginosa [23-26], R. glutinis [24, 27], and R. minuta [24].

The species $R$. oryzicola was isolated in the semiarid region of Bahia, with few records available so far. There are reports in the literature on its ability to produce cellulase, an enzyme characterized by its stability at high temperatures and activity at neutral pH [28]. Thus, this study aims to test the ability of $R$. oryzicola to produce proteases in different conditions, purify, characterize, and immobilize them in order to improve their stability at different $\mathrm{pH}$ and temperature values and, by enabling biocatalyst reuse, to develop more effective protease-based catalyzed processes.

\section{Materials and Methods}

\subsection{Microorganism used}

Samples of $R$. oryzicola for fermentation runs were obtained from the Culture Collection of Microorganisms, from Bahia, of the State University of Feira de Santana (UEFS). The yeast was grown in YM agar medium $(0.3 \%$ malt extract, $0.3 \%$ yeast extract, $0.5 \%$ peptone, $1 \%$ glucose, $2 \%$ agar, and chloramphenicol) at $28{ }^{\circ} \mathrm{C}$ for $72 \mathrm{H}$. All experiments were performed in triplicate.

\subsection{Selection of medium for the fermentation process} The yeast $R$. oryzicola was fermented in different media containing gelatin and casein, according to the following formulations: (i) casein medium containing glucose, peptone, yeast extract, and casein; (ii) malt extract medium with $2 \%$ malt extract and 1\% gelatin; (iii) Sabouraud medium with peptone and glucose. The formulation that promoted the best result was used as basis to implement other statistical tests.

\subsection{Fermentation}

For inoculum standardization, the colonies were inoculated in a Petri dish containing YM agar medium and incubated at $28{ }^{\circ} \mathrm{C}$ for $72 \mathrm{H}$. After this time interval, the colonies were diluted in $0.45 \%$ saline solution in order to reach a standardized inoculum of $10^{7}$ microorganisms upon spectrophotometric readings at $600 \mathrm{~nm}$. Next, $10 \mathrm{~mL}$ of inoculum was inoculated in $100 \mathrm{~mL}$ of medium. Submerged fermentation was carried out at $28{ }^{\circ} \mathrm{C}$ under $100 \mathrm{rpm}$ orbital shaking (TECNAL 720), and after $120 \mathrm{H}$ the biomass was separated from the enzyme-rich supernatant by centrifugation $\left(10,000 \mathrm{~g} / 10 \mathrm{Min} / 4{ }^{\circ} \mathrm{C}\right)$.

\subsection{Determination of proteolytic activity}

The casein digestion method was used to determine proteolytic activity [29]. The reaction mixture containing $100 \mu \mathrm{L}$ of enzymatic extract and $1 \mathrm{~mL}$ of $0.5 \%$ casein, prepared in sodium phosphate buffer (0.2 M, pH 6.0), was incubated for $20 \mathrm{Min}$ at $35^{\circ} \mathrm{C}$. At the end of the reaction, an aliquot of $100 \mu \mathrm{L}$ of the mixture was collected and added to $5 \mathrm{~mL}$ of the Bradford reagent [30], followed by a spectrophotometer (Varian-Cary 50) reading at $595 \mathrm{~nm}$.

One enzyme unit (U) was defined as the amount of enzyme as necessary to consume $1 \mu \mathrm{g}$ of casein per minute (expressed as $\mathrm{U} / \mathrm{mL}$ ). The specific activity was determined by the ratio between enzyme activity $(\mathrm{U} / \mathrm{mL})$ and protein concentration $(\mathrm{mg} / \mathrm{mL})$ and was expressed as U/mg. All measurements were performed in triplicate. 


\subsection{Purification}

The enzyme was purified from the culture filtrate using $70 \%$ ethanol solution and Sephacryl-S200 column chromatography.

Seventy percent of ethanol solution was added to $3 \mathrm{~mL}$ of the crude enzyme extract in a $2: 1(\mathrm{v} / \mathrm{v})$ ratio. The tubes containing the solution were left to stand for $15 \mathrm{Min}$, after which they were centrifuged at $10,000 \mathrm{~g}$, at $4{ }^{\circ} \mathrm{C}$ for $15 \mathrm{Min}$. The supernatant was discarded, and $50 \mathrm{mM}$ phosphate buffer was added in the same amount as the initial extract to resuspend the precipitate.

After ethanol precipitation, $1 \mathrm{~mL}$ of the solution containing the enzyme sample was applied to the Sephacryl - S200 column $(1.1 \times 20 \mathrm{~cm})$ using the Akta Prime system (Amersham Bioscience®) equilibrated with $50 \mathrm{mM}$ sodium phosphate buffer, pH 7.0.

\subsubsection{Determination of total proteins}

The total protein concentration throughout the different steps in protease purification was determined using the Bradford method [30], with bovine serum albumin as reference protein for the standard curve.

\subsection{Determination of optimum $\mathrm{pH}$ and temperature} Response surface methodology was used to predict the effect of operational $\mathrm{pH}$ and temperature in enzyme activity. The Doehlert experimental design had two variables, activity temperature and $\mathrm{pH}$, and three replicates at the center of the domain, totaling nine experiments. Casein $(0.5 \%)$ was prepared in sodium phosphate buffer for the $\mathrm{pH}$ values: 5.5, 6.0, 6.5, 7.0, and 7.5. The experiments were carried out at different temperatures for $20 \mathrm{Min}$, and the specific enzyme activity (U/mg) was quantified at each point.

The data obtained were transformed into relative proteolytic activity for plotting the graphs. Experimental errors were evaluated based on the replication of the central point. The experimental data were processed using the STATISTICA software version 7.0, where the lack of fit of the model to the experimental data was also tested through analysis of variance (ANOVA).

\subsection{Effect of ions on enzyme activity}

The following salts were added to the reaction medium, containing casein as substrate: magnesium chloride $\left(\mathrm{MgCl}_{2}\right)$, calcium chloride $\left(\mathrm{CaCl}_{2}\right)$, sodium chloride $(\mathrm{NaCl})$, potassium chloride (KCl), ammonium chloride $\left(\mathrm{NH}_{4} \mathrm{Cl}\right)$, barium chloride $\left(\mathrm{BaCl}_{2}\right)$, cobalt chloride $\left(\mathrm{CoCl}_{2}\right)$, aluminum sulfate $\left(\mathrm{Al}_{2}\left(\mathrm{SO}_{4}\right)_{3}\right)$, magnesium sulfate $\left(\mathrm{MgSO}_{4}\right)$, ferrous sulfate $\left(\mathrm{FeSO}_{4}\right)$, manganese sulfate $\left(\mathrm{MnSO}_{4}\right)$, ammonium sulfate $\left(\left(\mathrm{NH}_{4}\right)_{2} \mathrm{SO}_{4}\right)$, potassium sulfate $\left(\mathrm{K}_{2} \mathrm{SO}_{4}\right)$, and sodium sulfate $\left(\mathrm{Na}_{2} \mathrm{SO}_{4}\right)$ in concentrations of $0.1 \mathrm{M}$ and $0.01 \mathrm{M}$. Activity without the addition of ions was set at $100 \%$. The enzymatic activity was determined as described in Section 2.4.

\subsection{Thermostability}

Thermostability was assessed by collecting enzyme samples at different time intervals $(0,10,20,30,40,50$, and 60 Min) upon incubation at different temperatures $(50,60,70,80$, and $90{ }^{\circ} \mathrm{C}$ ). After this incubation period, the test tubes containing the enzymes were cooled in an ice bath and enzyme activity was evaluated as described in Section 2.4.

\subsection{Enzyme immobilization}

Three commercially available carriers were tested for enzyme immobilization: silica gel, Celite 545, and chitosan (Sigma Chemical Co., St Louis, MO, USA). $0.5 \mathrm{~mL}$ of $50 \mathrm{mM}$ phosphate buffer pH 6.5 and $0.10 \mathrm{~g}$ of each support to be tested were added to $1 \mathrm{~mL}$ of crude enzyme extract of protease. The suspension was thoroughly mixed by stirring $(100 \mathrm{rpm})$ at $25^{\circ} \mathrm{C}$ for 120 Min. Carrier particles containing the immobilized enzyme were allowed to settle by gravity, the supernatant was removed with a micropipette, and the immobilized enzyme was washed twice with $2.5 \mathrm{~mL}$ of the same buffer. After sedimentation, the supernatant was removed with a micropipette. The amount of proteins in the supernatants and the enzyme activity of the immobilized crude extract (CE) were evaluated.

Enzyme immobilization was evaluated according to the following parameters:

(1) Yield of the immobilization process (\%):

$$
\mathrm{YP}=\frac{\text { Activity of the immobilized CE }}{\text { Activity of the } \mathrm{CE}} \times 100
$$

(2) Protein retention (\%) (amount of immobilized enzyme):

$$
\operatorname{PR}(\%)=\frac{\text { Protein in the supernatant }}{\text { Total protein in the CE }} \times 100
$$

\subsubsection{Determination of the optimum temperature and pH of the immobilized enzyme}

The proteolytic activity of the immobilized enzyme was evaluated at different temperatures $\left(50,70\right.$, and $\left.90{ }^{\circ} \mathrm{C}\right)$ and at different $\mathrm{pH}$ values $(5.5,6.0,6.5,7.0,7.5)$, with casein solution $(0.5 \%)$ in $0.2 \mathrm{M}$ sodium phosphate buffer. The experiments were carried for $20 \mathrm{Min}$, and the specific enzyme activity (U/mg) was quantified at each point. The data obtained were transformed into relative proteolytic activity for plotting the graphs.

\subsubsection{Reuse of the immobilized enzyme}

The reuse of the immobilized enzyme was carried out in 20 Min batch runs. After each run (cycle), the immobilized enzyme was washed twice with $2.5 \mathrm{~mL}$ of $50 \mathrm{mM}$ phosphate buffer, $\mathrm{pH}$ 6.5. After sedimentation, the supernatant was removed with a micropipette and the enzymatic activity of the immobilized crude extract was performed according to Section 2.4. The result was presented in relative activity (\%), and the activity in the first cycle was set at $100 \%$. All tests were performed in triplicate.

\subsubsection{Thermostability of the immobilized enzyme}

The thermostability of the immobilized enzyme was evaluated by collecting biocatalyst samples at different time intervals $(0$, $10,20,30,40,50$, and $60 \mathrm{Min})$ upon incubation at different temperatures $\left(50,60,70,80\right.$, and $\left.90^{\circ} \mathrm{C}\right)$. After this incubation 


\begin{tabular}{lcccc} 
& Total protein $(\mathrm{mg})$ & Activity $(\mathrm{U} / \mathrm{mL})$ & Specific activity $(\mathrm{U} / \mathrm{mg})$ & Purification fold \\
\hline Crude extract & 1.97 & 0.1262 & $6.54 \times 10^{-3}$ & 1.00 \\
Gel filtration & 0.23 & 0.403 & $2.01 \times 10^{-2}$ & 3.07
\end{tabular}

period, biocatalyst activity was evaluated as described in Section 2.4.

\section{Results and Discussion}

\subsection{Microorganism and selection of the culture medium for fermentation}

The genus Rhodotorula has been shown to be a producer of proteolytic enzymes, hence strains from this genus are sound candidates to screen for protease activity [23,31-33]. The yeast $R$. oryzicola was selected for the production of protease because it was previously isolated from an environment that experiences extreme climate conditions that change during the year. In order to thrive under such harsh conditions, the metabolic apparatus of this yeast is likely to be adapted to the production of biomolecules, such as enzymes, resistant to different temperatures, an attractive feature for industrial application. Accordingly, $R$. oryzicola has been shown to produce a thermophilic cellulase but its potential as suitable source of enzymes for industrial application is vastly unexplored [34]. In this study, it was possible to evidence the ability of $R$. oryzicola to produce proteases.

Among the three different media used for the production of protease, the casein-containing medium allowed the highest expression of proteases, with specific activity of $6.54 \times$ $10^{-3} \mathrm{U} / \mathrm{mg}$, followed by malt extract medium (specific activity of $\left.5.7 \times 10^{-3} \mathrm{U} / \mathrm{mg}\right)$ and by peptone-containing medium $(4.6 \times$ $10^{-3} \mathrm{U} / \mathrm{mg}$ ). In the study by Chandrasekaran and Sathiyabama [35], casein at a concentration of $1 \%$ was selected as a suitable inducer for protease production, while other inducers tested led to low levels of protease production.

The production of proteases generally requires complex sources of nitrogen, such as casein, peptone, or yeast extract. The protease of R. mucilaginosa was significantly secreted in the presence of peptone, while enzyme activity increased by the interaction between low concentrations of glucose and peptone [23].

Previous studies showed that protease production by R. mucilaginosa was dependent on the composition of the medium, the optimal production conditions involving the use of peptone, casein, and glucose as nitrogen and carbon sources [33]. The availability of nutrients in the culture medium can also regulate the expression and secretion of different sets of proteases, as well as their biochemical properties, through the use of different types of substrate as source of carbon and nitrogen $[36,37]$.
Thus, it was shown that different compositions of the fermentation medium can directly influence enzyme production by the same microbial species. This still corroborates the work by Chaud et al. [23] who suggested that microorganisms have individual nutritional preference for maximum enzyme production.

\subsection{Purification of the enzyme}

The enzyme was purified in two steps with a final specific activity of $2.01 \times 10^{-2}$ (U/mg). Purification with gel filtration proved to be efficient, as it increased the specific activity of the enzyme till 3.07-fold over the levels in the crude extract (Table 1).

After ethanol precipitation and Sephacryl-S200 column chromatography, spectrophotometric reading at $280 \mathrm{~nm}$ allowed to identify the significant absorbance peak in fractions 17-22. The same range of fractions depicted noticeable proteolytic activity, whereas other fractions did not depict proteolytic activity (Fig. 1).

Proteases of Graphium putredinis and Trichoderma harzianum were purified using ethanol precipitation and column chromatography, allowing for a recovery factor of up to $36.49 \%$ of the protein with purity increased up to 18.80 -fold [38]. The alkaline protease produced by Beauveria sp. was purified by ammonium sulfate precipitation and ion exchange chromatography, allowing for a 10.2-fold increase in purity and $38.6 \%$ protein recovery [39].

\subsection{Effect of $\mathrm{pH}$ and temperature on protease activity}

Each enzyme has an optimum $\mathrm{pH}$ and temperature. An enzyme can undergo ionizations and acquire momentary charges, as well as suffer the rupture of bonds due to the temperature of the medium leading to loss of catalytic activity [3]. The characterization of enzyme activity regarding this operational variable is paramount to identify the conditions that maximize activity.

The enzymatic assay at different incubation temperatures and $\mathrm{pH}$ values allowed to establish that the activity of the protease produced by $R$. oryzicola peaked at $60{ }^{\circ} \mathrm{C}$ and $\mathrm{pH}$ 6.5 (Table 2). Beyond these temperature and $\mathrm{pH}$ values, a decrease in proteolytic activity was observed, which is related to protein denaturation/unfolding. The $\mathrm{pH}$ of the reaction medium has been shown to modulate the activity of proteases [40].

This model was also used to generate response surface graphics. The statistical analysis of the effects of $\mathrm{pH}$ and temperature showed that temperature positively influenced 


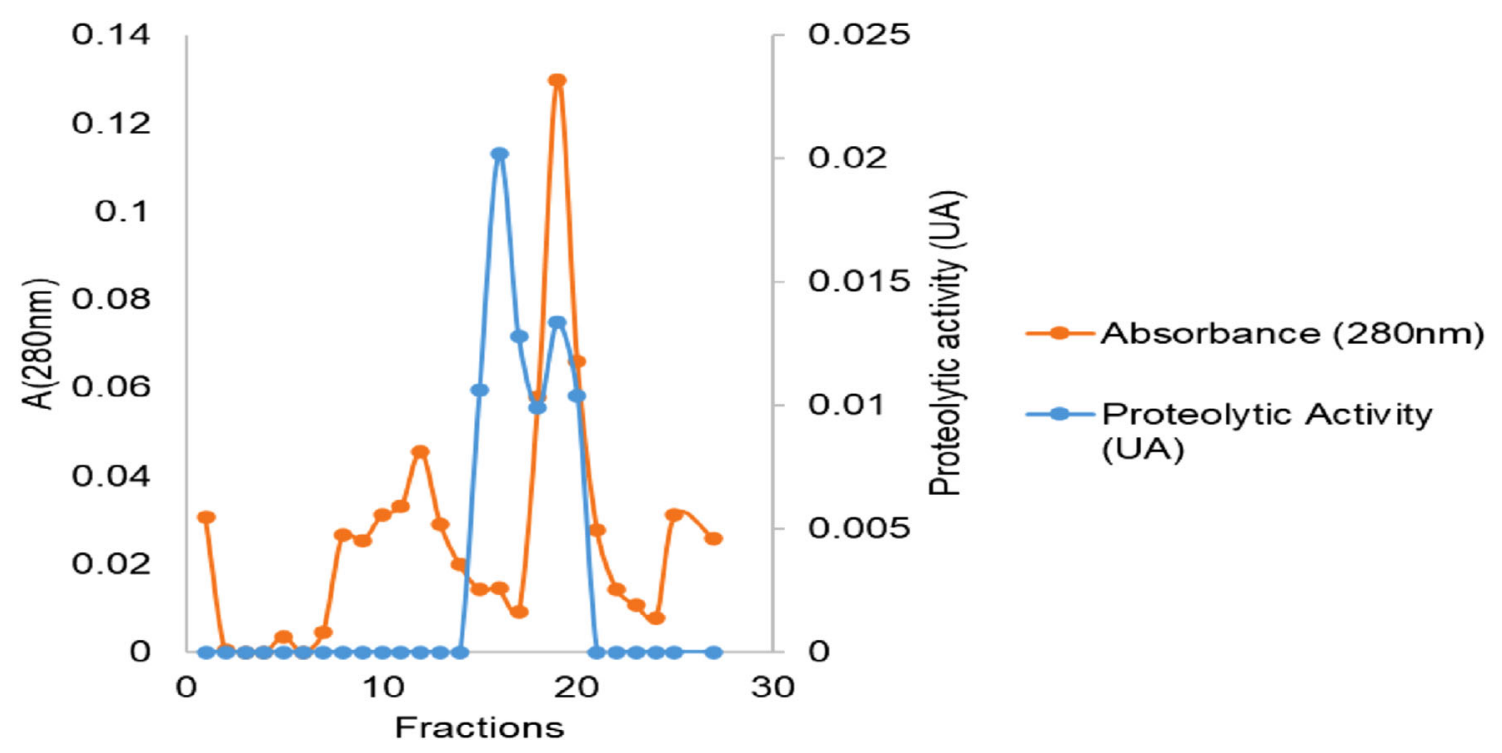

FIG. 1

Purification of R. oryzicola protease on Sephacryl S-200 column.

active is expected to contribute to bring the focus of research centers closer to industrial needs.

The model used is predictive because the regression coefficients were highly significant (21.36 and 9.48, respectively, for calculated $F$ and tabulated $F$ ), and the percentage of variation computed by the model proved to be adequate $\left(R^{2}\right.$ $=97 \%)$. As for the lack-of-fit test, the calculated $F(9.01)$ was lower than the tabulated $F$ (18.81), indicating that the residues did not significantly interfere with the results obtained (Table 3).

\subsection{Effect of salts on protease activity}

Enzymatic activity can be altered in the presence of some salts; they can increase the hydrolytic power or reduce the activity of enzyme, a behavior also reported when proteases are involved $[39,41,42]$.

Enzymatic activity was measured in the presence of each salt used at concentrations of $0.01 \mathrm{M}$ and $0.1 \mathrm{M}$. There was an increase in enzyme activity at $0.01 \mathrm{M}$ concentration, while at $0.1 \mathrm{M}$ concentration of some salts inactivated the enzyme. Table 4 shows percentages with standard deviations of the residual activity of the enzyme resulting from the addition of different salts.

A positive effect on the proteolytic activity was noticeable for different salts at a concentration of $0.01 \mathrm{M}$. Thus, in the presence of barium chloride and of manganese sulfate, the proteolytic activity increased up to $50 \%$ and $14 \%$, respectively, as compared to the activity without additives. When the concentration of salts was increased to $0.1 \mathrm{M}$, barium chloride continued to act as a cofactor, but with an increase in activity of only $6 \%$. Enzyme activity was reduced in the presence of the remaining salts, up to $73.4 \%$ in the presence of calcium chloride. Magnesium chloride and potassium chloride inactivated the enzyme. 

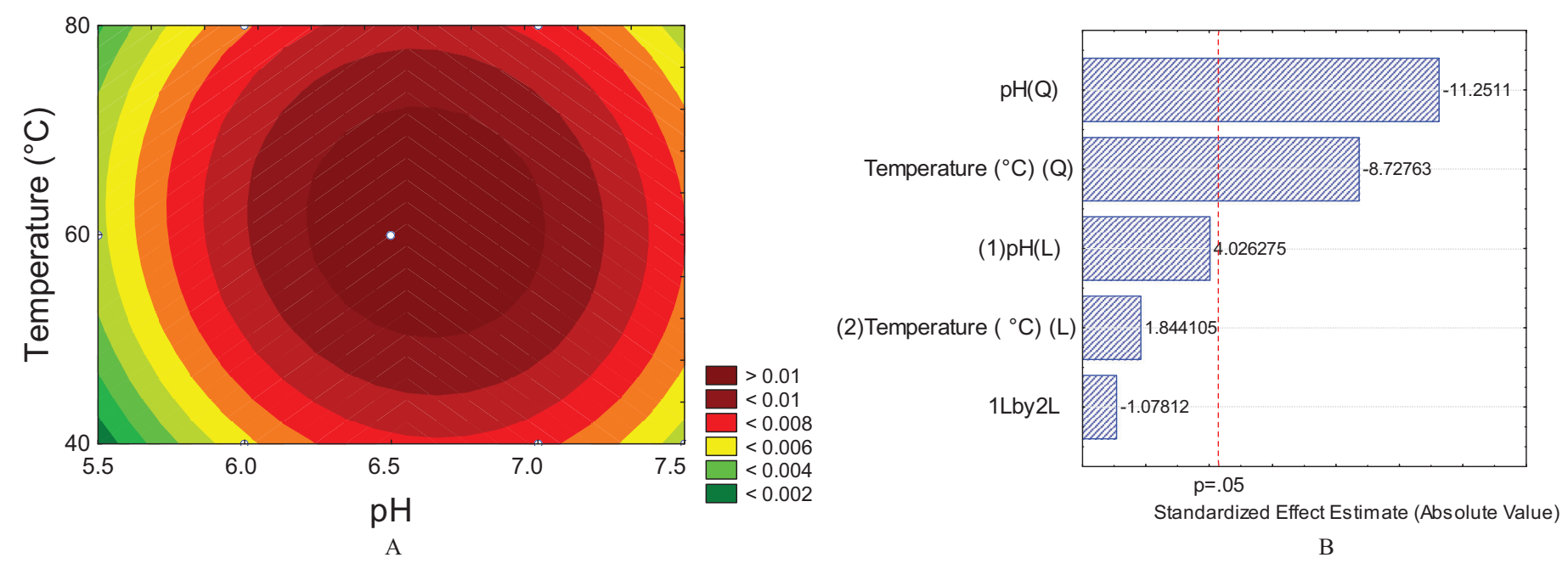

FIG. 2

(A) Response surface for optimization of protease characterization showing the effects of $\mathrm{pH}$ and temperature $\left({ }^{\circ} \mathrm{C}\right)$ for free enzyme. (B) Pareto chart of standardized effects of the variables studied in the planning.

TABLE 3

\begin{tabular}{lccccc} 
Variation source & $S Q$ & $D F$ & $O M$ & $F$ calculated & F tabulated (Cl 95\%) \\
\hline Regression & 0.10 & 5 & 0.019269 & 21.36466 & 9.01 \\
Residual & 0.00 & 3 & 0.000902 & & 18.81 \\
Lack-of-fit & 0.00 & 1 & 0.002234 & 9.482419 & \\
Pure error & 0.00 & 2 & 0.000236 & &
\end{tabular}

SO total

0.10

Abbreviations: $\mathrm{Cl}$, confidence interval; DF, degrees of freedom; QM, quadratic mean; QS, quadratic sum.

The catalytic activity of the protease produced by Cryptococcus sp. was increased by about $22 \%$, upon addition of $\mathrm{MgCl}_{2}$ to the reaction medium, compared to the control without additives, whereas $\mathrm{Ca}^{2+}$ had negligible influence on the enzyme activity [16]. The proteolytic activity of the enzyme produced by $R$. mucilaginosa decreased by $20 \%$ in the presence of $\mathrm{NaCl}$ at the concentration between 0.5 and 1.0 M. However, it remained stable without losing activity at higher concentrations of $\mathrm{NaCl}$ [33]. Stability and increased activity of the enzyme in the presence of $\mathrm{BaCl}_{2}$ and $\mathrm{MnSO}_{4}$ at low concentrations makes the use of these salts suitable as additives for future formulations for the production of protease by $R$. oryzicola.

\subsection{Thermostability}

As for the thermostability of the protease, long-term residual activity tests were carried out in the temperature range from 50 to $90{ }^{\circ} \mathrm{C}$. The protease of $R$. oryzicola presented a good thermostability profile, retaining about $90 \%$ of activity at temperatures between 50 and $60{ }^{\circ} \mathrm{C}$, while activity was reduced to $75 \%$ at 70,80 , and $90{ }^{\circ} \mathrm{C}$ (Fig. 3).
Thermophilic microorganisms are obvious sources of thermostable enzymes. However, these enzymes can also be obtained from mesophilic and even psychrophilic microorganisms. This was corroborated by Lario et al. [33] who investigated the features of the protease of $R$. mucilaginosa, a yeast isolated from an Antarctica seaweed from, and observed that the enzyme had optimal activity at $50{ }^{\circ} \mathrm{C}$.

The protease of $R$. oryzicola showed to be suitable for industrial applications, which generally require proteases that are both active and stable under relatively hostile conditions, often comprising extremes of temperature and $\mathrm{pH}$ [43].

\section{Enzyme Immobilization}

Enzyme activity was evaluated on all carriers used for immobilization. Irrespectively of the carrier used, immobilized enzyme activity exceeded that of the free enzyme (Table 5). This result is promising because immobilization by adsorption can be easily performed. As the immobilized enzyme can be 


\section{TABLE 4}

Evaluation of enzymatic activity under the effect of different salts at a concentration of $0.1 \mathrm{M}$ and $0.01 \mathrm{M}$. The control activity was taken as $100 \%$

\begin{tabular}{lcr}
\multirow{2}{*}{ Salt } & \multicolumn{2}{c}{ Residual activity $\%$ (average $+\mathrm{DP}$ ) } \\
\cline { 2 - 3 } & \multicolumn{1}{c}{$0.01 \mathrm{M}$} & \multicolumn{1}{c}{$0.1 \mathrm{M}$} \\
\hline Control & 100 & 100 \\
$\mathrm{Na}_{2} \mathrm{SO}_{4}$ & $90.71 \pm 0.0002$ & $93.48 \pm 0.0008$ \\
$\mathrm{~K}_{2} \mathrm{SO}_{4}$ & $79.86 \pm 0.0001$ & $94.91 \pm 0.0001$ \\
$\left(\mathrm{NH}_{4}\right)_{2} \mathrm{SO}_{4}$ & $90.54 \pm 0.0009$ & $63.7 \pm 0.0001$ \\
$\mathrm{MnSO}_{4}$ & $114.28 \pm 0.0001$ & $44.59 \pm 0.0006$ \\
$\mathrm{FeSO}_{4}$ & $83.57 \pm 0.0007$ & $83.07 \pm 0.0001$ \\
$\mathrm{MgSO}_{4}$ & $84.28 \pm 0.0001$ & $59.24 \pm 0.0002$ \\
$\mathrm{Al}_{2}\left(\mathrm{SO}_{4}\right)_{3}$ & $106.96 \pm 0.0002$ & $73.11 \pm 0.0007$ \\
$\mathrm{CaCl}_{2}$ & $135 \pm 0.0001$ & $26.6 \pm 0.0007$ \\
$\mathrm{NaCl}$ & $21.42 \pm 0.0001$ & $33.33 \pm 0.0002$ \\
$\mathrm{MgCl}_{2}$ & $69 \pm 0.0004$ & - \\
$\mathrm{KCl}$ & $107 \pm 0.0001$ & - \\
$\mathrm{NH}_{4} \mathrm{Cl}$ & $104 \pm 0.0008$ & $46.66 \pm 0.0004$ \\
$\mathrm{BaCl}_{2}$ & $150 \pm 00002$ & $106.66 \pm 0.0004$
\end{tabular}

-: absence of enzymatic activity.

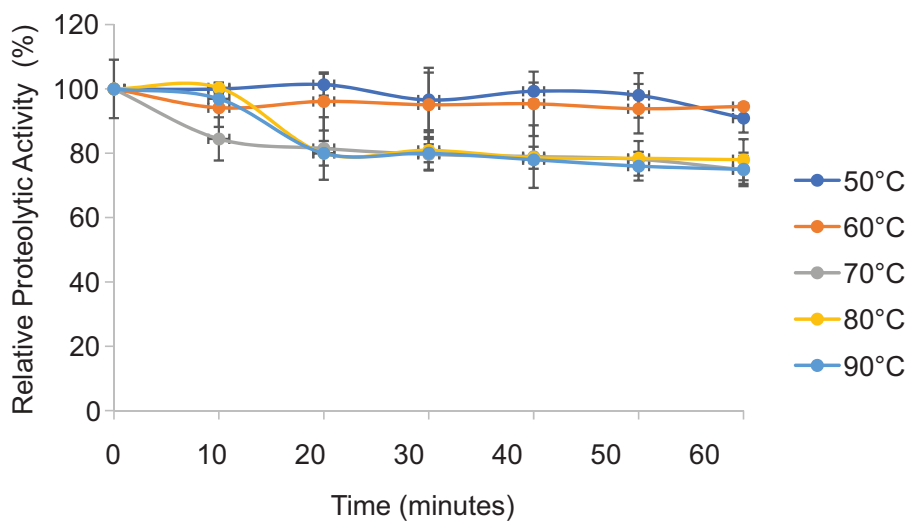

FIG. 3

Thermostability of R. oryzicola protease.

reused for several catalytic cycles, there is also a reduction in the cost of producing and obtaining the enzyme.

The highest immobilization yield (262.32\%) and protein retention $(47 \%)$ were observed when protease was immobilized in chitosan, besting the immobilization yield in Celite 545 and silica gel by a little over twofold and protein retention,

\section{TABLE 5}

Total protein concentration in the supernatant after immobilization and enzyme activity of free and immobilized protease by $\mathbf{R}$. orizycola adsorption. The activity of the free enzyme was set at $100 \%$

\begin{tabular}{lcc} 
Sample & Total protein & Enzyme activity $(\mathrm{U} / \mathrm{mg})$ \\
\hline Free enzyme & $61.85 \pm 0.322$ & $3.6 \times 10^{-3} \pm 0.008$ \\
Silica gel & $39.37 \pm 0.380$ & $1.07 \times 10^{-2} \pm 0.008$ \\
Celite 545 & $46.30 \pm 0.972$ & $1.11 \times 10^{-2} \pm 0.018$ \\
Chitosan & $32.78 \pm 0.0503$ & $5.44 \times 10^{-2} \pm 0.089$
\end{tabular}

TABLE 6

Support

Silica ge

Celite 545

Chitosan

by roughly 1.3 -fold and 1.9-fold in silica gel and Celite 545 , respectively (Table 6).

Chitosan is a natural polymer that has been widely used as a carrier for enzyme immobilization [44]. Such wide use of chitosan can be ascribed to the ability of the polymer to retain twice as many enzymes due to the existence of some hydroxyl and amino groups that bind to the enzyme more easily, and also to the high porosity of chitosan [45-47]. These characteristics may have influenced the activity of the protease produced by $R$. orizycola, increasing it by up to $262 \%$ compared to the control.

The silica used in the immobilization of enzymes is an attractive support to the industrial sector due to its toxicological safety and its ability to promote the stability of the enzyme and its reuse [48] besides long-term durability and efficiency [49]. Moreover, silica-immobilized enzymes have been shown to outperform the free form, as reported by Soleimani et al. [50].

The use of Celite 545 as protease carrier proved more promising than other types of inorganic supports [51]. Celite 545 is a highly porous material, with low cost and large adhesion area, also showing chemical inertia and has been used to immobilize different enzymes with excellent results [52-54].

To expand the large-scale use of immobilized enzymes requires the resolution of technological challenges, such as the constant search for new supports and immobilization protocols that maintain the catalytic activity of the enzyme after the immobilization process [55].

\subsection{Reuse of the immobilized enzyme}

Immobilized enzyme formulations were evaluated throughout for 15 reuse cycles (Fig. 4). Although the protease immobilized in chitosan showed excellent results in the hydrolysis of the 


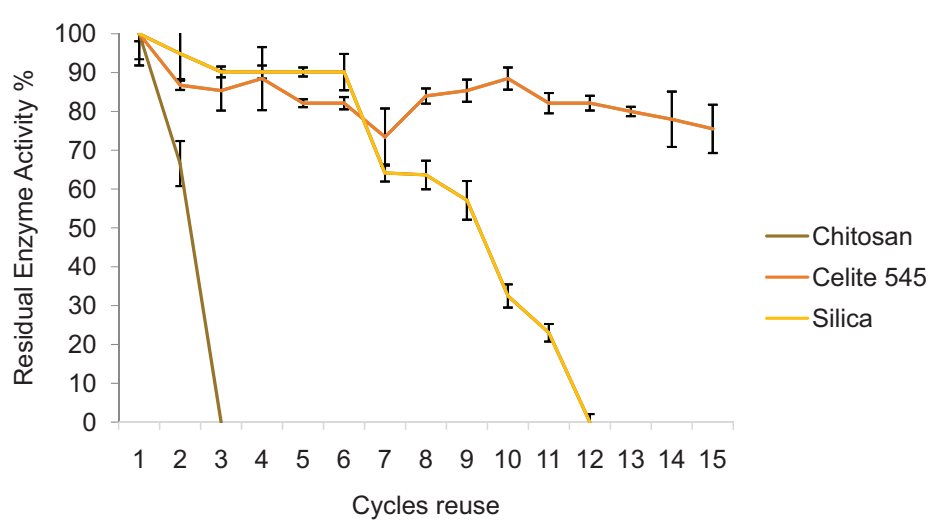

FIG. 4

Operational stability of R. oryzicola protease immobilized on different supports. Activity obtained in the first cycle was taken as $100 \%$ activity.

protein, it falls short in operational stability, since the residual activity of the immobilized enzyme decreased to $67 \%$ after the first cycle. After the second cycle, the chitosan-immobilized protease lost all catalytic activity, so the use of this enzyme formulation was discontinued.

The residual activity of the silica-gel based biocatalyst decreased to $22.9 \%$ in the 11 th reuse cycle, and, like the chitosan support, its use was discontinued. The loss of activity of the immobilized enzyme can probably be due to conformational changes, instability enzyme, and leakage [56, 57].

The protease immobilized in Celite 545, on the other hand, showed good stability throughout the 15 reuse cycles, with a final residual activity of $73.53 \%$. According to reports in the literature, immobilized enzymes that retain up to $50 \%$ of their initial activity after 10 successive reuse cycles are considered to have excellent operational stability [58, 59].

With the technique of enzymatic immobilization on solid supports and subsequent reuse of the enzyme, it is possible to reduce the costs of enzyme production, since new processes of enzyme production and purification become unnecessary [60].

The results confirmed that the protease produced by $R$. oryzicola immobilized by adsorption on Celite 545 had increased stability and reuse. This support should therefore be used, as it is an excellent carrier for enzyme immobilization. Moreover, it has been suggested that carriers allowing for activity retention above $60 \%$ of the initial activity of the enzyme after 15 reuse cycles are recommended for further focused studies with enzyme immobilization [61].

\subsection{Optimization of the $\mathrm{pH}$ and temperature of the protease produced by $R$. oryzicola immobilized on Celite 545}

The enzymatic assay under different temperatures and $\mathrm{pH}$ of incubation showed that the highest activity of the protease produced by $R$. oryzicola immobilized on the inorganic support Celite 545 occurred at $60{ }^{\circ} \mathrm{C}$ and $\mathrm{pH} 6.5$ (Table 7). At other
TABLE 7

Doehlert experimental design for optimization of the enzymatic activity of $\mathbf{R}$. oryzicola protease immobilized on Celite 545

\begin{tabular}{llll} 
Experiment & $\begin{array}{c}\text { Temperature } \\
\left({ }^{\circ} \mathrm{C}\right)\end{array}$ & $\mathrm{pH}$ & $\begin{array}{l}\text { Enzyme } \\
\text { activity }\end{array}$ \\
\hline 1 & 80 & 6.0 & 0.0428 \\
2 & 80 & 7.0 & 0.0954 \\
3 & 60 & 5.5 & 0.1166 \\
$4(\mathrm{C})$ & $60(\mathrm{C})$ & $6.5(\mathrm{C})$ & 0.2739 \\
$5(\mathrm{C})$ & $60(\mathrm{C})$ & $6.5(\mathrm{C})$ & 0.2368 \\
$6(\mathrm{C})$ & $60(\mathrm{C})$ & $6.5(\mathrm{C})$ & 0.2739 \\
7 & 40 & 7.5 & 0.09980 \\
8 & 40 & 6.0 & 0.1220 \\
9 & 40 & 7.0 & 0.1146
\end{tabular}

temperatures, it was possible to observe a decrease in residual activity. Studies that seek to characterize the effect of temperature as well as the effect of $\mathrm{pH}$ on enzyme activity are important to determine the ideal conditions of the enzyme [62].

Based on the Doehlert matrix and using the STATISTICA 7.0, it was possible to establish that catalytic activity peaked at of $59.54^{\circ} \mathrm{C}$ and $\mathrm{pH} 6.82$. The optimum temperature of the immobilized enzyme was slightly lower than the optimum temperature of the free enzyme.

This matrix model was used to generate response surface graphics and a Pareto diagram, indicating that the optimal activity of the enzyme is located at the central point of the matrix and that both temperature and $\mathrm{pH}$ influence the activity of this enzyme at the level of significance of $5 \%(P<0.5)$ (Figs. 5A and 5B).

The model used is predictive, since the values of the regression coefficients were highly significant (28.39 and 0.76 , respectively, for calculated $F$ and tabulated $F$ ), and the percentage of variation computed by the model proved to be adequate $\left(R^{2}=97 \%\right)$. As for the lack-of-fit test, the calculated $F=9.01$ was smaller than the tabulated $F=18.81$, indicating that the residues did not significantly interfere with the results obtained (Table 8).

\subsection{Thermostability of the enzyme immobilized on Celite 545}

The immobilized protease from $R$. oryzicola displayed thermostability profile that was less favorable than that of the free enzyme. The protease of $R$. oryzicola presented a good thermostability profile, retaining more than $90 \%$ of activity at $50{ }^{\circ} \mathrm{C}$ for up to $60 \mathrm{Min}$, at $60{ }^{\circ} \mathrm{C}$, the residual activity was above $90 \%$ only for 20 Min, falling to $40 \%$ after 60 Min of incubation. At $70{ }^{\circ} \mathrm{C}$, there was a $20 \%$ loss of residual activity in the first $10 \mathrm{Min}$, and the enzyme showed about $30 \%$ of residual 

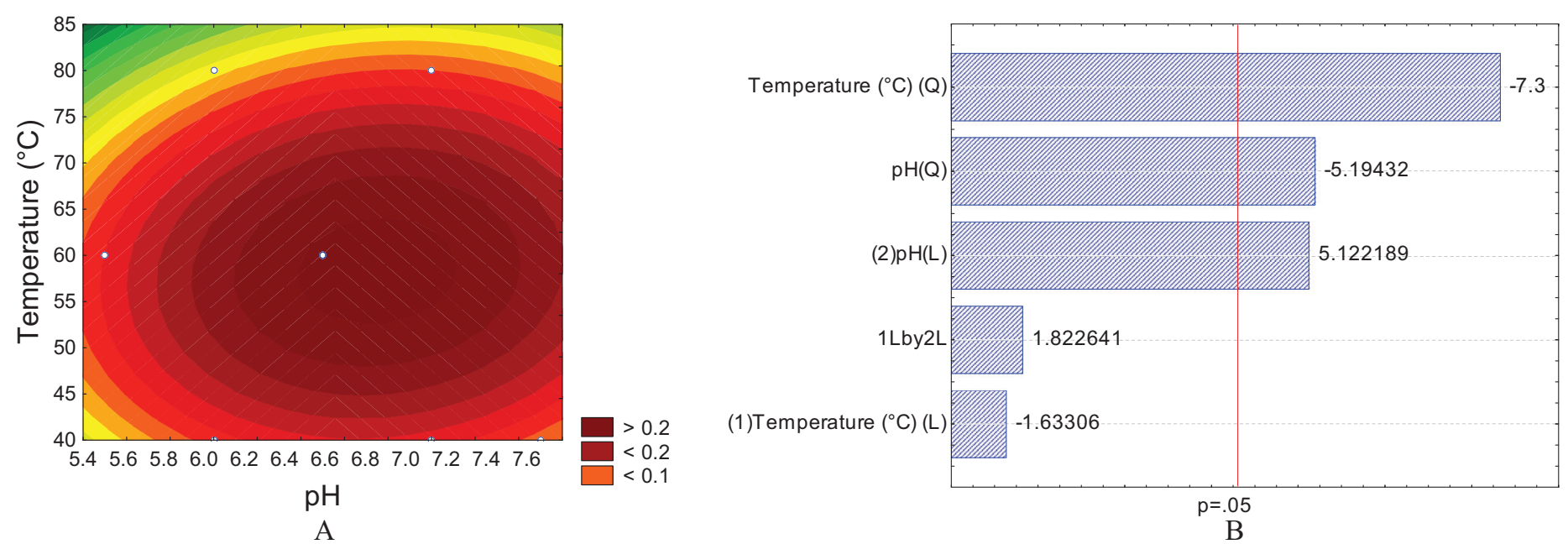

(A) Response surface for optimization of protease characterization showing the effects of $\mathrm{pH}$ and temperature $\left({ }^{\circ} \mathrm{C}\right)$ for

FIG. 5 immobilized enzyme. (B) Pareto chart of standardized effects of the variables studied in the planning-influence of $\mathrm{pH}$ and temperature on the proteolytic activity of the R. oryzicola enzyme immobilized in Celite 545.

TABLE 8

ANOVA for optimization of protease activity immobilized on Celite 545 support

\begin{tabular}{lccccr} 
Variation source & $S Q$ & DF & OM & F calculated & F tabulated (Cl 95\%) \\
\hline Regression & 0.13 & 5 & 0.026 & 28.39631 & 9.01 \\
Residual & 0.00 & 4 & 0.000916 & & 0.972599 \\
Lack-of-fit & 0.00 & 1 & 0.000744 & 0.764515 & 18.81 \\
Pure error & 0.00 & 3 & 0.000973 & &
\end{tabular}

SQ total $\quad 0.13$

Abbreviations: $\mathrm{Cl}$, confidence interval; DF, degrees of freedom; QM, quadratic mean; QS, quadratic sum;

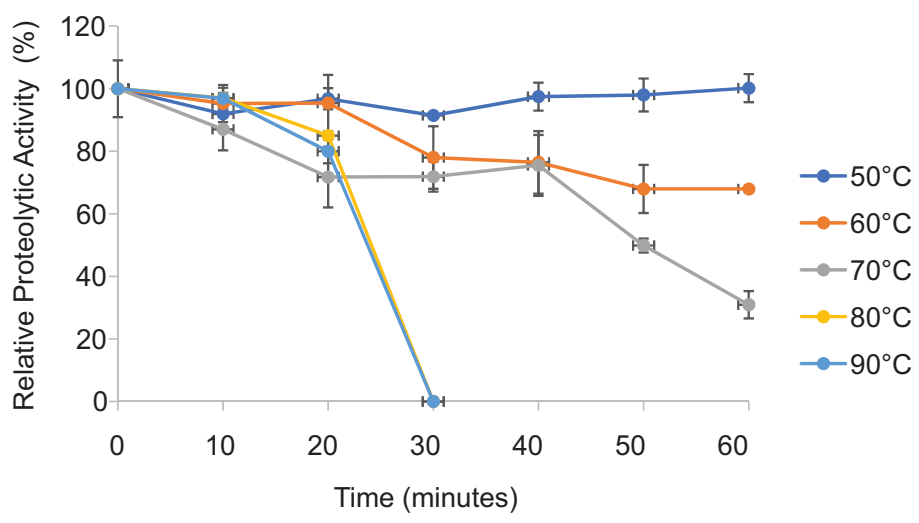

FIG. 6

Thermostability of immobilized R. oryzicola protease in Celite 545.

activity after $60 \mathrm{Min}$ at that temperature. At 80 and $90{ }^{\circ} \mathrm{C}$, the enzyme showed activity only in the first 20 Min of incubation (Fig. 6).
This difference in stability may be related to the fact that the immobilized enzyme has a more rigid conformation, since it is linked to the support, and when denaturation occurs, the enzyme remains in this state, losing part or all of its catalytic activity. The free enzyme goes through a cooling process right after incubation at different temperatures, which can influence the native conformation of the enzyme, allowing it to exert its total or partial catalytic activity.

Crescimbeni et al. [63] suggested that high temperatures affect the dissociation state of the ionizable functional groups involved in enzyme activity and in the interaction with the substrate, leading to the denaturation and ultimate inactivation of the protease. Celite 545 likely lacks a good mechanism of heat absorption from the external environment, making it impossible to minimize the temperature increase inside the enzyme microenvironment, leading to its inactivation.

\section{Conclusion}

The present work focused on the production of proteases from the yeast $R$. oryzicola isolated in the semiarid region of Bahia, 
an unprecedented finding for the species, which proved to be a good producer of the enzyme of interest. The data found in this study indicate that the enzyme, in either free or immobilized form, can be used in biotechnological processes that require adverse operational conditions, since both had their optimum point of operation above $50{ }^{\circ} \mathrm{C}$. The enzyme also showed good thermal stability, with a half-life of $60 \mathrm{Min}$.

The carrier selected for immobilization proved to be efficient, retaining up to $73 \%$ of catalytic activity, after 15 reuse cycles, without the need for new production, thus lowering the costs of enzyme production. Therefore, Celite 545 is suggested as a sound carrier for enzyme immobilization.

\section{Acknowledgements}

The authors would like to thank the Fundação de Amparo à Pesquisa do Estado da Bahia (FAPESB), Coordenação de Aperfeiçoamento Pessoal de Nível Superior (CAPES), CNPq, and the Postgraduate Program in Biotechnology, UEFS, for financial support and scholarship.

\section{Conflict of Interests}

The authors declare that there are no conflicts of interest.

\section{References}

[1] Kumar, V., Singh, D., Sangwan, P., and Gil, K. (2014) In: V Beniwal and A K. Sharma (Eds.), Industrial Enzymes: Trends, Scope and Relevance. Nova Science, Hauppauge, NY, pp. 173-196.

[2] Kuddus, M. (2019) Enzymes in Food Biotechnology: Production, Applications, and Future Prospects. Academic Press, New York, p. 909.

[3] Daiha, K. G., Brêda, G. C., Larentis, A. L., Freire, D. M. G., and Almeida, R. V. (2016) Braz. J. Sci. Technol. 3, 17. https://doi.org/10.1186/s40552-016-0029-0

[4] Singh, R., Mittal, A., Kumar, M., and Mehta, P. K. (2016) J. Pharm. Chem. Biol. Sci. 4, 365-374.

[5] Li, S., Yang, X., Yang, S., Zhu, M., and Wang, X. (2012) Compu. Struct. Biotechnol. J. 2, e201209017. https://doi.org/10.5936/csbj.201209017

[6] Liu, L., Yang, H., and Shin, H. D. (2013) Bioengineered. 4, 212-223. https: //doi.org/10.4161/bioe.24761

[7] Choi, J. M., Han, S. S., and Kim, H. S. (2015) Biotechnol Adv. 33, 1443-1454. https://doi.org/10.1016/j.biotechadv.2015.02.014

[8] Basso, A., and Serban, S. (2019) Mol. Catal. 479, 110607

[9] Joutey, N. T., Bahafid, W., Sayel, H., and Ghachtouli, N. E. (2013) In: R. Chamy, F. Rosenkranz (Eds.), Biodegradation - Life of Science, InTech, Rijeka, Croatia, pp. 291-321. https://doi.org/10.5772/56194.

[10] Barata, R. A., Andrade, M. H. G., and Rodrigues, R. D. (2002) J. Biosci. Bioeng. 94, 304-308. https://doi.org/10.1263/jbb.94.304

[11] Kumar, S., Sharma, N. S., Saharan, M. R., and Singh, R. (2005) Process Biochem. 40, 1701-1705. https://doi.org/10.1016/j.procbio.2004.06.047

[12] Adrio, J. L., and Demain, A. L (2014) Process. Biomol. 4, 117-139. https: //doi.org/10.3390/biom4010117

[13] Johnston, D. B, and Mcaloon, J. A. (2014) Bioresour. Technol. 154, 18-25. https://doi.org/10.1016/j.biortech.2013.11.043

[14] Frazier, W. C., and Westhoff, D. C. (1988) Food Microbiology. 4 ed. McGrawHill International Edition, New York.

[15] Mahajan, R. T., and Badgujar, S. B. (2010) J. Pharm. Res. 3, 2048-2068.

[16] . Zanphorlin, L. M, Cabral, H., Arantes, E.. Assis Juliano, D. L., Juliano, M. A., and Bonilla-Rodriguez, G. O. (2011) Process Biochem. 46, 2137-2143. https://doi.org/10.1016/j.procbio.2011.08.014
[17] Żymańczyk-Duda, E., Brzezińska-Rodak, M., Klimek-Ochab, M., Duda, M., and Agata Zerka, A. (2017) In: Yeast: Industrial Applications, A. Morata and I. Loira (Eds.). IntechOpen, London. https://doi.org/10.5772/intechopen.70130

[18] Kot, A. M., Błażejak, S., Kurcz, A., Gientka, I., and Kieliszek, M. (2016) Appl. Microbiol. Biotechnol. 100, 6103-6117. https://doi.org/10.1007/s00253-0167611-8

[19] Hernalsteens, S., and Maugeri, F. (2010) J. Food Biochem. 34, 520-534. https://doi.org/10.1111/j.1745-4514.2009.00295.x

[20] Tasar, C. O. (2017) Biocatal. Biotransform. 35, 191-197. https://doi.org/10. 1080/10242422.2017.1304386

[21] Ünlu, A. E., and Takac, S. (2012) Artif. Cells Blood Substit. Immobil. Biotechnol. 40, 338-345. https://doi.org/10.3109/10731199.2012.668910

[22] Wang, H., Peng, L., Wu, J., and Shi, G. (2015) Process Biochem. 50, 901-905. https://doi.org/10.1016/j.procbio.2015.03.004

[23] Chaud, L. C. S., Lario, L. D., Bonugli-Santos, R. C. Sette, L. D., Pessoa Jr, A., and Felipe, A. (2016) New Biotechnol. 33, 807-814. https://doi.org/10.1016/j. nbt.2016.07.016

[24] Neves, K. C. S., Porto, A. L. F., and Teixeira, M. F. S (2006) Acta Amaz. 36, 299-306. https://doi.org/10.1590/S0044-59672006000300002.

[25] Vaz, A. B. M., Rosa, L. H., Vieira, M. L. A., Garcia Brandão, L. R., and Teixeira, L. C. R. S. (2011) Braz. J. Microbiol. 42, 937-947. https://doi.org/10.1590/S151783822011000300012

[26] Duarte, A. W. F. Dayo-Owoyemi, I., Nobre, F. S., Pagnocca, F. C., Chaud, L. C. S. Pessoa, A., Felipe, M. G. A, and Sette, L. D. (2013) Extremophiles. 17, 1023-1035. https://doi.org/10.1007/s00792-013-0584-y

[27] Liu, C. L., and Hatano, H. (1974) FEBS Lett. 42, 352-354.

[28] Santana, M. L., Bispo, J. A. C., de Sena, A. R., Teshima, E., Brito, A. R., Costa, F. S., Franco, M., and Assis, S. A. (2020). J. Food Sci. Technol. https://doi.org/10.1007/s13197-020-04511-5

[29] Kunitz, M. (1947) J. Gen. Physiol. 30 295-310. https://doi.org/10.1085/jgp.30. 4.291

[30] Bradford, M. M. (1976) Anal. Biochem. 72, 248-254. https://doi.org/10.1006/ abio.1976.9999

[31] Kamada, M., Oda, K., and Murao, S. (1972) Agric. Biol. Chem, 36, 1095-1101. https://doi.org/10.1080/00021369.1972.10860377

[32] Chou, H., Tam, M. F., Lee, S. S., Tai, H. - Y., Chang, C. Y., Chou, C. T., and Shen, H.-D. A. (2005) Int. Arch. Allergy Immunol. 138, 134-141. https://doi.org/10.1159/000088435

[33] Lario, L. D., Chaud, L., Almeida, M., Converti, A., Sette, D. L., and Pessoa, A. (2015) Fungal Biol. 119, 1129-1136. https://doi.org/10.1016/j.funbio.2015.08.012

[34] Santana, M. L, Paulo, E. M., Bispo, J. A., Sena, A. R, and Assis, S. A. (2018) Preparative Biochem. Biotechnol. 48(2), 165-171, DOI: 10.1080/10826068.2017. 1421962

[35] Chandrasekaran, M., and Sathiyabama, M. (2013) J. Basic Microbiol. 54, 763-74. https://doi.org/10.1002/jobm.201200584

[36] Farnell, E., Rousseau, K., Thornton, D. J., Bowyer, P., and Herrick, S. E. (2012) Fungal Biol. 116, 1003-1012. https://doi.org/10.1016/j.molcatb.2011.06.003

[37] Speranza, P., Carvalho, P. O., and Macedo, G. A. (2011) J. Mol. Catal. B. 72, 181-186. https://doi.org/10.1016/j.molcatb.2011.06.003

[38] Savitha, S., Sadhasivam, S., Swaminathan, S., and Lin, F. H. (2011) J. Taiwan Inst. Chem. Eng. 42, 298-304. https://doi.org/10.1016/j.jtice.2010.05.012

[39] Shankar, S., Rao, M., and Laxman, R. S. (2011) Process Biochem. 46 579-585. https://doi.org/10.1016/j.procbio.2010.10.013

[40] Marciano, A. F., Coutinho-Rodrigues, C. J. B., Perinotto, W. M. S., Camargo, M. G., Gôlo, P. S., de Sá, F. A, Quinelato, S., Freitas, M. C., Angelo, I. C., Nogueira, M. R. S., and Bittencourt, V. R. E. P. (2015) Rev/ Bras. Med. Vet. 37, $85-90$.

[41] Zhang, J., Wang, J., Zhao, Y., Li, J., and Liu, Y. (2019) Int. J. Biol. Macromol. 124, 121-130. https://doi.org/10.1016/j.ijbiomac.2018.11.198

[42] Siala, R., Sellami-Kamoun, A., Hajji, M., Abid, I., Gharsallah, N., and Nasri, M. (2009) Afr. J. Biotechnol. 8, 4582-4589.

[43] Sharma, K. M., Kumar, R., Panwar, S., and Kumar, A. (2017) Genet. Eng. Biotechnol. 15, 115-126. https://doi.org/10.1016/j.jgeb.2017.02.001

[44] Mesquita, M. V. N., Gomes, L. S., Matos, L. F. L., Oliveira, A. B. M., Nunes, D. B., Cambrussi, A. N. C. O., Freitas, A. F., and Ribeiro, A. B. (2018) Boletim Inform. Geum. 9, 38-50. 
[45] Betigeri, S. S., and Neau, S. H (2002) Biomaterials. 23, 3627-3636. https: //doi.org/10.1016/s0142-9612(02)00095-9

[46] Chern, J. T., and Chao, Y. P. (2005) J. Biotechnol. 117, 267-275. http: //doi.org/10.1016/j.jbiotec.2005.02.001

[47] Chang, M. Y., and Juang, R. S. (2007) Biochem. Eng. J. 35, 93-98. https: //doi.org/10.1016/j.bej.2007.01.003

[48] Carvalho, N. B., Lima, Á. S., and Soares, C. M. Quím. Nova 399-409. https://doi.org/10.5935/0100-4042.20140304

[49] Popat, A., Hartono, S. B, Stahr, F., Liu, J., Qiao, S. Z., and Luo, G. Q. M. (2011) Nanoscale. 3, 2801-18. https://doi.org/10.1039/c1nr10224a

[50] Soleimani, M., Khani, A., and Najafzadeh, K. (2011) J. Mol. Catal. B Enzym. 74, 1-5. https://doi.org/10.1016/j.molcatb.2011.07.011

[51] Witono, Y., and Azkiyah, Y. L. (2016) Int. J. Adv. Sci. Eng. Inform. Technol. 6, 201-204. http://doi.org/10.18517/ijaseit.6.2.716

[52] Liu, C. H., Lin, Y. H., Chen, C. Y., and Chang, J. S. (2009) J. Taiwan Inst. Chem. Eng. 40, 359-363. https://doi.org/10.1016/j.jtice.2008.10.004

[53] Koszelewski, D., Müller, N., Schrittwieser, J. H., Faber, K., and Kroutil, W. (2010) Mol. Catal. B-Enzym, 63, 39-44. https://doi.org/10.1016/j.molcatb.2009. 12.001

[54] Ansari, S. A., and Husain, Q. (2012) Food Bioprod Process. 90 351-359. https://doi.org/10.1016/j.fbp.2011.07.003
[55] Souza, P. M, Werneck, G., Aliakbarian, B., Siqueira, F., Ferreira Filho, E. X., Perego, P., Converti, A., Magalhaes, P. O., and Pessoa Jr, A. (2017) Food Chem. Toxicol. 109, 1103-1110. https://doi.org/10.1016/j.fct.2017.03.055

[56] Mateo, C., Palomo, J. M., Fernandez-Lorente, G., Guisan, J. M., and Fernandez-Lafuente, R. (2007) Enzyme Microb. Technol. 40, 1451-1463. https://doi.org/10.1016/j.enzmictec.2007.01.018

[57] Talekar, S., Joshi, A., Joshi, G., Kamat, P., Haripurkar, R., and Kambale, S. (2013) RSC Adv. 3, 12485-12511.

[58] Cabrera-Padilla, R. Y., Lisboa, M. C., Fricks, A. T., Franceschi, E., Lima, A. S. Silva, D. P., and Soares, C. M. (2013) J. Ind. Microbiol. Biotechnol. 39, 289-98. https://doi.org/10.1007/s10295-011-1027-3

[59] Hu, T., Cheng, J., Zhang, B., Lou, W., Zong, M. (2015) Ind. Eng. Chem. Res. 54, 4689-4698. https://doi.org/10.1021/ie504691j

[60] Datta, S., Christena, L. R., and Rajaram, Y. R. S. (2013) 3 Biotech. 3, 1-9. https://doi.org/10.1007/s13205-012-0071-7

[61] Sankar, K., and Achary, A. (2020) Chemi. Pap. 74, 459-470. https://doi.org/10. 1007/s11696-019-00891-x

[62] Özacar, M., Mehde, A. A., Mehdi, W. A., and Özacar, Z. (2018) Int. J. Biol. Macromol. 117, 947-958. https://doi.org/10.1016/j.ijbiomac.2018.04.195

[63] Crescimbeni, M. C., Nolan, V., Clop, P. D., Marín, G. N., and Perillo, M. A. (2010) Colloids Surf. B. 76, 387-396. https://doi.org/10.1016/j.colsurfb.2009.11.005 